\title{
Overview on Application of Response Surface Methodology (RSM) in Treatment of Palm Oil Mill Effluent (POME)
}

\author{
Mohd Azwan Ahmad ${ }^{1}$, Luqman Chuah Abdullah ${ }^{1}$, Thomas Choong Shean Yaw ${ }^{1}$ and Abdul Wahab Mohammad ${ }^{2}$ \\ 1. Department of Chemical \& Environmental Engineering, Faculty of Engineering, University Putra Malaysia, Serdang 43400, Malaysia \\ 2. Department of Chemical \& Process Engineering, Faculty of Engineering, University Kebangsaan Malaysia, Bangi 43650, Malaysia
}

\begin{abstract}
There are many factors affecting the performance of a treatment system especially in the treatment of palm oil mill effluent (POME) as its contains high amounts of suspended solid, low $\mathrm{pH}$, high salt content and high chemical oxygen demand (COD). However, one factor at a time approach is complicated method in establishing relationship between multiple parameters. Response surface methodology (RSM) is a recommended approach as it is widely used to analyze and study the interactions between multiple parameters and provides optimum output as well as minimizing the defects which result in good treatment system. This paper overviews the recent and current research in the application of RSM in optimizing the treatment development of POME.
\end{abstract}

Key words: Palm oil mill effluent (POME), multiple parameters, response surface methodology (RSM).

\section{Introduction}

Malaysia was recognized as one of the world's largest exporters of palm oil. In 2012, Malaysia palm oil has accumulated 5.0 million hectares of land, producing 18.79 million tonnes of palm oil and 2.16 million tonnes of palm kernel oil [1]. Consequently, this also means the polluting wastewater, known as palm oil mill effluent (POME) has produced directly proportional to the large amount of palm oil production [2]. It is estimated that 5-7 tonnes of water are required to extract 1 tonnes of crude palm oil production and more than $50 \%$ of the water will end up as POME [3]. Many treatment and removal methods of POME have been investigated and proposed in order to eliminate the pollution caused by the palm oil industry. However, each treatment process depends on many process variables and optimization of these processes may increase their efficiency [4].

Response surface methodology (RSM) is a

Corresponding author: Luqman Chuah Abdullah, Ph.D., Professor, main research: wastewater treatment. E-mail: chuah@upm.edu.my. recommended approach as it is widely used to analyze and study the interactions between multifactors [5]. It is based on collection of mathematical and statistical techniques which are useful for developing, improving, and optimizing of processes involved. Basically, a response of interest is influenced by several variables and the objective of RSM is to optimize this response. In order to analyze the effects of the independent variables, this experimental methodology will create a mathematical model which explains the chemical and biochemical processes [6, 7]. In recent years, the application of RSM has been applied for optimization in numerous chemical and biochemical processes and this also includes the treatment of POME. This paper discussing the general application of RSM which is used for modeling and optimizing the treatment of POME towards better treatment process.

\section{Materials}

\subsection{Palm Oil Mill Effluent (POME) Characteristics}

Palm oil mill effluent (POME) which obtained from the clarification process of oil mill contains of various 
suspended compounds, including cell walls, organelles, short fibre, series of carbohydrates ranging from hemicelluloses to simple sugars, a range of nitrogenous mixtures from protein to amino-acids, free organic acids and a compilation of minor organic and mineral constituents [8]. However, the contents in the POME are non-toxic, but release an unpleasant odor [9]. POME is generated from three main processes and these includes sterilizer condensate, hydrocylone waste and separator sludge [10]. POME is a thick, more to acidic with a $\mathrm{pH}$ value between in 4.0-5.0, and brownish in color liquid with the temperature ranging from $80{ }^{\circ} \mathrm{C}$ to $90{ }^{\circ} \mathrm{C}$ during discharged. The properties of POME are 95\%-96\% water, $0.6 \%-0.7 \%$ of oil and grease and $4 \%-5 \%$ of total solids [11]. Table 1 shows the typical characteristics of raw POME [12-14].

Due to the high quantity of pollution source in raw POME, the needs of proper treatment system is important. Most palm oil mills and refineries have their own treatment systems in treating POME and normal application is ponding system as it was applied to more than $85 \%$ of palm oil mill in Malaysia [15]. In general, ponding system is recognized as stabilization ponds and oxidation ponds where the term oxidation also refers as aerobic and anaerobic ponds [16].
2.2. Theory and Fundamental of Response Surface Methodology (RSM)

In the appplications of RSM, the use of experimental design and multiple regression-based methods can be applied in order to evaluate the process where several independent variables (factors) might influence dependent variables (responses) [17]. There are three steps involved in the application of RSM, these include: (1) design of experiment; (2) modeling of RSM through regression and (3) optimization of RSM.

\subsubsection{Design of Experiment}

The important section in the RSM is a design of experiment where its objective is to select the points in order to evaluate the response. There are three popular experimental designs, namely (1) three-level factorial design; (2) Box-Behnken design (BBD) and (3) central composite design (CCD).

The three-level factorial design consists of all possible combinations of $-1,0$ and +1 which indicate as minimum level, intermediate level and maximum level respectively. The number of runs in the three-level factorial design depends on $3^{k}$, where, $k$ is the number of available independent variables.

The Box-Behnken design is a fractional $3^{k}$ factorials, which are performed by combining two-level factorial

Table 1 Characteristics of raw palm oil mill effluent.

\begin{tabular}{lll}
\hline Parameter & Standard by DOE $(\mathrm{mg} / \mathrm{L})$ & Concentration $(\mathrm{mg} / \mathrm{L})$ \\
\hline Chemical oxygen demand & 100 & 50,000 \\
Biochemical oxygen demand & 50 & 25,000 \\
Oil and grease & 10 & $4,000-6,000$ \\
Total solids & NA & 40,500 \\
Suspended solids & 400 & 18,000 \\
Total volatile solids & NA & 34,000 \\
Calcium & NA & 439 \\
Potassium & NA & 2,270 \\
Phosphorus & NA & 180 \\
Boron & 4.0 & 7.6 \\
Iron & 5.0 & 46.5 \\
Manganese & 1.0 & 2.0 \\
Copper & 1.0 & 0.89 \\
Magnesium & NA & 615 \\
Zinc & 1.0 & 2.3 \\
\hline
\end{tabular}


design with incomplete block designs [18]. In BBD, the level of one of the factors is fixed at the center while all possible combinations of other factor are applied [19]. The number of runs in BBD is given by $2 k(k-1)+\mathrm{c}_{\mathrm{p}}$, where, $k$ is the number of factors and $c_{p}$ is the number of central points [20].

CCD was introduced by Box and Wilson in year 1951 which consists of a two-level factorial design, a center point and an axial point. Generally, CCD requires 5 levels of each factor which are called $-\alpha,-1$, 0,1 , and $+\alpha$. The total number of experimental runs of CCD is given by the expression $2^{k}+2 k+n_{c}$, where $n_{c}$ is the number of center points [21].

\subsubsection{Modeling of RSM through Regression}

The objective of the RSM is to build the regression model which acts as an approximation model in order to establish results as a true regression model. The first order of the response surface model can be expressed as:

$$
y=f\left(x_{1}, x_{2}, x_{3}, \ldots, x_{k}\right)
$$

Where, $y$ is the response and $x_{i}$ are factors.

The aim of RSM is to optimize the response $y$, since the first order are not applicable in analyzing the interaction effect between different parameters and cannot determine the critical points, the second order or the response surface model is generally used in RSM which can be expressed as:

$$
y=\beta_{0}+\sum_{i=1}^{k} \beta_{i} x_{i}+\sum_{i=1}^{k} \beta_{i i} x_{i}^{2}+\sum_{i=1}^{k=1} \sum_{j=2}^{k} \beta_{i j} x_{i} x_{j}+\varepsilon
$$

Where, $x_{i}$ and $x_{j}$ are the input factors which influence the response $y ; \beta_{0}, \beta_{i}, \beta_{i i}$, and $\beta_{i j}$ are regression coefficients for intercept, linear, quadratic and interaction coefficients respectively and $\varepsilon$ is a random error.

2.2.3 Optimization of RSM in the Treatment of POME

The response surface design can be used to investigate the optimum value of the response over entire variable space and in its region when it reaches the optimum value. In RSM, desirability function is commonly used to determine the optimal of multiple responses [22]. For each response, a desirability function assigns numbers between 0 and 1 to the possible values of response. If the desirability function is equal to 0 , it represents a completely undesirable value of the response, and if the desirability function is equal to 1 , it represents a completely desirable or ideal response value.

\section{Results and Discussion}

\subsection{Application of RSM in the Treatment of POME}

In recent years, there are a large number of studies reported on the use of RSM for analysis of different processes used in the treatment of water and wastewater including POME. Some of these are discussed in this section.

\subsection{Anaerobic Treatment}

An anaerobic process in treating industrial wastewater such as POME is highly recommended which results in higher treatment efficiency, lower energy requirement and minimizes the amount of sludge production $[23,24]$. The common application of anaerobic process in treating POME is open tank digester and extended aeration systems [25]. Since the anaerobic process is influenced by multiple factors such as feed concentration, alkalinity, biomass concentration, flow rate, and so on, the use of RSM can be advantageously as it is applicable in findings the optimum results. Zinatizadeh et al. [26] used the application of RSM in analyzing the optimum conditions of POME treatment using an up-flow anaerobic sludge fixed film bioreactor. Feed flow rate and up-flow velocity were the factors considered, while total chemical oxygen demand (TCOD) removal, soluble COD (SCOD) removal, effluent $\mathrm{pH}$, effluent total volatile fatty acid (TVFA), effluent bicarbonate alkalinity (BA), effluent total suspended solids (TSS), methane percentage in biogas, methane yield $\left(Y_{M}\right)$, specific methanogenic activity (SMA), 
food-to-microorganism ratio $(\mathrm{F} / \mathrm{M})$, sludge height in the UASB portion and solid retention time (SRT) were the responses studied. The experiments of 13 runs were conducted based on a central composite face-centered design (CCFD) and analyzed using response surface methodology (RSM). The optimum conditions were obtained based on 6 critical responses which are TCOD removal, $\mathrm{pH}, \mathrm{BA}$, methane yield, SRT and effluent TSS as these criteria are the most important parameters in optimizing anaerobic treatment process. The experimental result shows that the maximum feed flow rate $2.45 \mathrm{~L} / \mathrm{d}$ and up-flow velocity $0.75 \mathrm{~m} / \mathrm{h}$ give the optimum conditions for POME treatment which produces $92.62 \%$ of TCOD removal, $93.16 \%$ of SCOD removal, 7.53 of effluent $\mathrm{pH}, 43.1 \mathrm{mg}$ acetic acid/l of effluent TVFA, $1,520 \mathrm{mg}$ $\mathrm{CaCO}_{3} / \mathrm{L}$ of BA, $200 \mathrm{mg} / \mathrm{L}$ of effluent TSS, $70.83 \%$ of $\mathrm{CH}_{4}$ percentage, $0.313 \mathrm{lCH}_{4} / \mathrm{gCOD}_{\text {rem }} \mathrm{d}$ of methane yield, $54.4 \%$ of sludge height and $226.3 \mathrm{~d}$ of SRT. The application of RSM in this study shows that the experimental value is as close as model prediction which works well in identifying the optimum condition.

Similar studies are also done by Zinatizadeh et al. [27] in the treatment of POME using anaerobic process. However, this research has focused on the effect of pretreatment. Two types of pretreatment namely physical and chemical pretreatment are applied before the anaerobic process in order to remove or reduce the amount of suspended solid in the POME. Further, the application of RSM was applied for the optimum analysis based on a central composite face-centered design (CCFD) with two independently operating variables; feed flow rate and up-flow velocity. 13 runs were conducted in each experiment and 6 dependent parameters were measured as responses, namely total COD (TCOD) removal, effluent $\mathrm{pH}$, effluent total volatile fatty acid (TVFA), effluent bicarbonate alkalinity (BA), methane yield $\left(Y_{M}\right)$ and solids retention time (SRT). Based on the experimental performance, the physical pretreatment shows a better result compared to chemical pretreatment in terms of anaerobic treatment process. Both optimum conditions were feed flow rate of 1.65 L/d, up-flow velocity of 0.6 and feed flow rate of 2.45 $\mathrm{L} / \mathrm{d}$, up-flow velocity of 0.75 , respectively.

In other research, Sompong O-Thong et al. [28] used RSM with CCD to investigate the removal of chemical oxygen demands (COD) in the anaerobic treatment of POME by microorganism as seed sludge. The seed sludge is identified as Thermoanaerobacterium. Twenty runs of experiments were performed where iron concentration, $\mathrm{C} / \mathrm{N}$ ratio, and $\mathrm{C} / \mathrm{P}$ ratio were factors considered. COD removal was a single response in term of the anaerobic process of POME. Generally, normal application of anaerobic process requires a lot of retention time in order to reduce the content of COD. However, by applying the seed sludge, specific microorganism will enhance the performance of the treatment and increase the process efficiency. The optimum conditions were found at iron concentration of $200 \mathrm{mg} / \mathrm{L}, \mathrm{C} / \mathrm{N}$ ratio of 70 and $\mathrm{C} / \mathrm{P}$ ratio of 550 where COD removal efficiency of $56.4 \%$. It was observed that the application of RSM was useful for optimizing COD reduction from POME with Thermoanaerobacterium as seed sludge.

\subsection{Coagulation-Flocculation Process}

Coagulation-flocculation is a common process used in water and wastewater treatment in order to destabilize the colloidal particles where ferric chloride and/or polymer are added as destabilization agents [29]. Throughout the process, many factors can influence its efficiency, such as dosage of coagulant-flocculant, $\mathrm{pH}$, temperature, turbidity, retention time and so on. The use of RSM to optimize this factor may significantly increase the performance of the process. Ahmad et al. [30] had conducted a series of experiment on the treatment of POME based on RSM where treatment optimization was performed using jar tests. A CCD was applied to justify the effect and interaction of three factors; coagulant dosage, flocculent dosage, and $\mathrm{pH}$, while water recovery and turbidity were acting as 
a response. A CCD of 20 runs, including six replicates at the centre point was used in the RSM. The results showed that $78 \%$ of water recovery with a 20 NTU turbidity was the optimum value which can be obtained at a coagulant dosage of $15,000 \mathrm{mg} / \mathrm{L}$, a flocculant dosage of $300 \mathrm{mg} / \mathrm{L}$, and $\mathrm{pH}$ 6. The verification experiments demonstrate that the application of RSM works well for optimizing the coagulation-flocculation process. The optimum conditions obtained from the compromise regression equation were turbidity of 19 NTU and water recovery of $76 \%$.

The RSM was used by Bhatia et al. [31] to optimize the suspended solids and sludge recovery in regards to the treatment of POME by using a natural coagulant known as Moringa oleifera. A most common coagulant is actually a chemical based, however the increasing in price and environmental concern, natural coagulant which was friendly to the environment presented as an alternative for the treatment of wastewater such as POME. A $2^{4}$ factorial design of 30 experiments with eight star points and six replicates at the central points were employed in the RSM. After screening the experiments, $\mathrm{pH}$, settling time, M. oleifera dosage (after oil extraction), and flocculant dosage were selected as factors, while suspended solids and sludge recovery was the response studied. The optimum conditions were obtained at $\mathrm{pH}$ 5, settling time of $114 \mathrm{~min}$, M. oleifera dosage of $3,469 \mathrm{mg} / \mathrm{L}$ and flocculant dosage of 6,736 $\mathrm{mg} / \mathrm{L}$, where the suspended solid value was $181 \mathrm{mg} / \mathrm{L}$ and percentage recovery of the sludge was $87 \mathrm{wt} \%$. The use of M. oleifera alone is highly economical as it can reduce the cost of chemicals used for $\mathrm{pH}$ adjustment and also reduce the amount of sludge volume as well as the sludge handling cost.

\subsection{Solubilization}

Optimization of thermo-chemical treatment of POME using RSM was studied by Chou et al. [32]. The input variables included $\mathrm{NaOH}$ concentration $(1.27-14.73 \mathrm{~g} / \mathrm{L})$, incubation time $(7.64-88.36 \mathrm{~h})$ and temperature $\left(26.6-43.4^{\circ} \mathrm{C}\right)$, while COD solubilization was the single response. This study concentrated on the effects of temperature, $\mathrm{NaOH}$ concentration and reaction time on the solubilization of POME, while a CCD was applied to determine the corresponding optimum condition. Six axial points and three central points were augmented in the design with a total number of experiments were 20 runs. The COD solubilization was calculated based on the ratio of soluble chemical oxygen demand (SCOD) to total chemical oxygen demand (TCOD in percentage. The optimum condition obtained is $8.83 \mathrm{~g} / \mathrm{L}$ of $\mathrm{NaOH}$, at $32.5^{\circ} \mathrm{C}$ and $41.23 \mathrm{~h}$ reaction time in response to the maximum COD solubilization of $82.63 \%$. The experiment also runs in triplicate in order to confirm the prediction and the result obtained is close to the predicted value. This also indicates that the solubilization of POME can be optimized to the application of RSM.

Table 2 shows the summary of the experimental design used to optimize the treatment of POME. It is noted that the central composite design is the single model used by most POME studies for utilizing the analytical procedures. The main reason $\mathrm{CCD}$ was always used in many researches is because it can utilize and optimize a large number of factors and all experiments can also be conducted at the same time instead of one after another [33]. This method will also reduce the time consumed for each experiment and have a shorter research project duration.

\section{Conclusion}

The application of response surface methodology in modeling and optimizing the treatment development of POME is a highly efficient approach because it is applicable in identifying the most significant operating factor to optimize the response with minimum effort and time. Furthermore, it also helps to evaluate the effect of multiple variables on the response and their interactions which result in efficient treatment systems. 
Table 2 Summary of the experimental design for the treatment of POME.

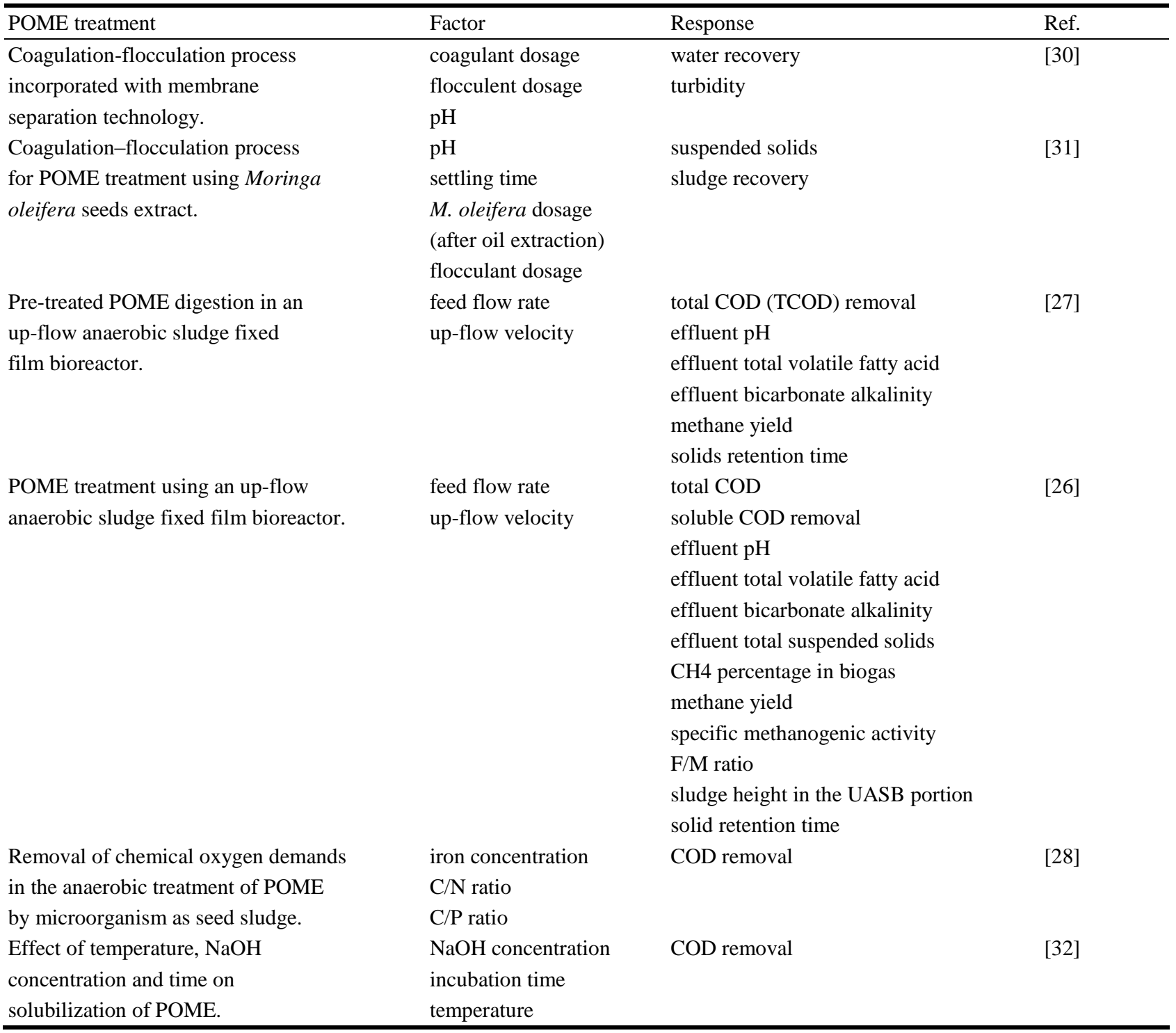

As shown in this paper, the central composite design is a most common experimental design used for the development of analytical procedures. This is because its ability to integrate with higher numbers of variables and its efficiency in optimizing the process which leads to the increasing number of published works in this field. In order to improve the application of RSM in optimizing the treatment process of POME, more studies and researches are needed with the possibility of combining or comparing with other modeling techniques such as artificial neural network (ANN) where its provides non-linear modeling for response surfaces and optimization in the treatment of POME.

\section{References}

[1] Malaysian Palm oil Association. 2015. "Market Report March, 2013." Malaysian Palm Oil Council. Accessed February 21, 2015. http://www.mpoc.org.my/The_Oil_ Palm_Tree.aspx.

[2] Ahmad, A.L., Chong, M.F., Bhatia, S., and Ismail, S. 2006. "Drinking Water Reclamation from Palm Oil Mill Effluent (POME) using Membrane Technology." Desalination 191 (1): 35-44.

[3] Ahmad, A. L., Ismail, S., and Bhatia, S. 2003. "Water Recycling from Palm Oil Mill Effluent (POME) using 
Membrane Technology." Desalination 157 (1): 87-95.

[4] Wang, J. P., Chen, Y. Z., Ge, X. W., and Yu, H. Q. 2007. "Optimization of Coagulation-Flocculation Process for A Paper-Recycling Wastewater Treatment using Response Surface Methodology." Colloids and Surfaces A: Physicochem. Eng. Aspects. 302 (1): 204-210.

[5] Abalos, A., Maximo, F., Manresa, M. A., and Bastida, J. 2002. "Utilization of Response Surface Methodology to Optimize the Culture Media for the Production of Rhamnolipids by Pseudomonas aeruginosa AT 10." Journal of Chemical Technology and Biotechnology 77 (7): 777-784.

[6] Anjum, M. F., Tasadduq, I., and Al-Sultan, K. 1997. "Response Surface Methodology: A Neural Network Approach." European Journal of Operational Research 101 (1): 65-73.

[7] Myers, R. H., and Montgomery, D. C. 1997. Response Surface Methodology: Process and Product Optimization using Designed Experiments. New York: John Wiley \& Sons, Inc.

[8] Esther O. U.1997. "Anaerobic Digestion of Palm Oil Mill Effluent and Its Utilization as Fertilizer for Environmental Protection." Renewable Energy 10 (2): 291-294.

[9] Ahmad, A. L., Chong, M. F., and Bhatia, S. 2007. "Mathematical Modeling of Multiple Solutes System for Reverse Osmosis Process in Palm Oil Mill Effluent (POME) Treatment." Chemical Engineering Journal 132 (1): 183-193.

[10] Borja, R. 1995. "Comparison of an Anaerobic Filter and an Anaerobic Fluidized Bed Reactor Treating Palm Oil Mill Effluent." Process Biochemistry 30 (6): 511-521.

[11] Ahmad, A. L., Sumathi, S., and Hameed, B. H. 2006. "Coagulation of Residue Oil and Suspended Solid in Palm Oil Mill Effluent by Chitosan, Alum and PAC." Chemical Engineering Journal 118 (1): 99-105.

[12] Environmental Requirements, 2010. "Environmental Quality (Sewage and Industrial Effluents) Regulation, 1979." Department of Environment. Accessed January 15, 2015. http://www.doe.gov.my/.

[13] Ma, A. N. 1999a. Treatment of Palm Oil Mill Effluent. "In: G. Singh, K.H. Lim, T. Leng and L.K. David (eds). Oil Palm and the Environment: a Malaysian Perspective." Malaysian Oil Palm Growers' Council 11 (5): 87-395.

[14] Ma, A. N. 2000. "Environmental Management for the Palm Oil Industry." Palm Oil Dev 30 (1): 1-10.

[15] Ma, A. N., Cheah, S. C., Chow, M. C. 1993. "Current Status of Palm Oil Processing Wastes Management." In Waste Management in Malaysia: Current Status and Prospects for Bioremediation, edited by B. G., Yeoh, K. S., Chee, S. M., Phang, Z., Isa, A., and Idris, M. Mohamed. Malaysia: Ministry of Science, Technology and the Environment. 111-136.

[16] Wong, K. K. 1980. “Application of Ponding Systems in the Treatment of Palm Oil Mill and Rubber Mill Effluents." Pertanika 3 (2): 133-141.

[17] Gardiner, W. P., and Gettinby, G. 1998. Experimental Design Techniques in Statistical Practice: A Practical Software-based Approach. London: Woodhead Publishing.

[18] Box, G. E. P., and Behnken, D. W. 1960. "Some New Three Level Designs for the Study of Quantitative Variables." Technometrics 2 (4): 455-475.

[19] Myers, R. H., Montgomery, D. C., 2002. Response Surface Methodology Process and Product Optimization using Designed Experiments. A Wiley-Interscience Publication. 2nd ed. Canada: John Wiley and Sons.

[20] Bezerra, M. A., Santelli, R. E., Oliveiraa, E. P., Villar, L. S., and Escaleira, L. A. 2008. "Response Surface Methodology (RSM) as A Tool for Optimization in Analytical Chemistry.” Talanta 76 (5): 965-977.

[21] Hang, Y., Qu, M., and Ukkusuri, S. 2011. "Optimizing the Design of A Solar Cooling System Using Central Composite Design Techniques." Energy and Buildings 43 (4): 988-994.

[22] Kalil, S., Maugeri, F., and Rodrigues, M. I. 2000. "Response Surface Analysis and Simulation as A Tool for Bioprocess Design and Optimization." Process Biochemistry 35 (6): 539-550.

[23] Castillo, A., Cecchi, F., and Mata-Al Varez, J. 1997. “A Combined Anaerobic-Aerobic System to treat Domestic Sewage in Coastal Areas." Water Research 31 (12): 3057-3063.

[24] Del Pozo, R. Diez, V. 2003. "Organic Matter Removal in Combined Anaerobic-Aerobic Fixed-Film Bioreactors." Water Research 37 (15): 3561-3568.

[25] Chan, Y. J., Chong, M. F., and Law, C. L. 2012. "An Integrated Anaerobic-Aerobic Bioreactor (IAAB) for the Treatment of Palm Oil Mill Effluent (POME): Start-up and Steady State Performance." Process Biochemistry 47 (3): 485-495.

[26] Zinatizadeh, A. A. L., Mohamed, A. R., Abdullah, A. Z., Mashitah, M. D., Hasnain Isa, M., and Najafpour, G. D. 2006. "Process Modeling and Analysis of Palm Oil Mill Effluent Treatment in An Up-Flow Anaerobic Sludge Fixed Film Bioreactor using Response Surface methodology (RSM)." Water Research 40 (17): 3193-3208.

[27] Zinatizadeh, A. A. L., Mohamed, A. R., Abdullah, A. Z., Mashitah, M. D., and Hasnain Isa, M. 2007. "Optimization of Pre-Treated Palm Oil Mill Effluent Digestion in An Up-Flow Anaerobic Sludge Fixed Film Bioreactor: A Comparative Study." Biochemical Engineering Journal 35 (2): 226-237. 
[28] Thong, S., Prasertsan, P., Intrasungkha, N., Dhamwichukorn, S., and Birkeland, N. 2008. "Optimization of Simultaneous Thermophilic Fermentative Hydrogen Production and COD Reduction from Palm Oil Mill Effluent by Thermoanaerobacterium-Rich Sludge." International Journal of Hydrogen Energy 33 (4): 1221-1231.

[29] Amuda, O. S., and Amoo, I. A. 2007. "Coagulation/flocculation Process and Sludge Conditioning in Beverage Industrial Wastewater Treatment." Journal of Hazardous Materials 141 (3): 778-783.

[30] Ahmad, A. L., Ismail, S., and Bhatia, S. 2005. "Optimization of Coagulation-Flocculation Process for Palm Oil Mill Effluent using Response Surface Methodology.” Environmental Science Technology 39 (8):
2828-2834.

[31] Bhatia, S., Othman, Z., and Ahmad A. L. 2007. "Coagulation-Flocculation Process for POME Treatment using Moringaoleifera Seeds Extract: Optimization Studies." Chemical Engineering Journal 133 (1): 205-212.

[32] Chou, K. W., Norli, I., and Anees, A. 2010. "Evaluation of the Effect of Temperature, $\mathrm{NaOH}$ Concentration and Time on Solubilization of Palm Oil Mill Effluent (POME) using Response Surface Methodology (RSM)." Bioresource Technology 101 (22): 8616-8622.

[33] Massart D. L., Vandeginste B. G. M., Buydens L. M. C., De Jong, S., Lewi, P. J., and Smeyers-Verbeke, J. 1998. Handbook of Chemometrics and Qualimetrics: part A. In Data Handling in Science and Technology Netherlands: Elsevier. 